\title{
A Bird's Eye View on the Status of the Module "Life Skills" in the Foundation Phase at Higher Education Institutions in South Africa
}

\begin{abstract}
This paper explores how the foundation phase subject area of "life skills" is being offered at $(n=9)$ higher education institutions (HEIs) in South Africa. The aim of the study, about which we report, was to identify similarities and differences in the curricula offered at these institutions and to establish the extent to which the different modules attend to the various aspects of life skills according to the most recent national curriculum. We conducted semi-structured interviews with participants who teach the subject at universities and we also analysed curriculum documents. We worked with a purposive sample of 9 respondents from the respective universities. The study found that although universities use the CAPS (national curriculum) document as guideline for structuring their curricula in teacher education programmes, some participants indicated that they follow an integrated approach, thereby implying that the different components of the school curriculum as outlined in the CAPS document are not specifically accommodated within their programmes. An additional finding was that there is a vast difference in the range of credits allocated to the various aspects of life skills that may restrict social mobility between various $\mathrm{HEls.}$
\end{abstract}

Keywords: Life skills, foundation phase, curriculum and assessment policy statement; higher education institutions

Miemsie Steyn, University of Pretoria.E-mail: mg.steyn@up.ac.za.Cycil Hartell, University of Pretoria. E-mail: cycil.hartell@up.ac.za. N Schuld, Tshwane University of Technology. E-mail: schuldn@tut.ac.za 


\section{Introduction}

Universities are traditionally viewed as autonomous institutions of learning and research that are devoted to the examination, production, appraisal, dissemination and transmission of knowledge as well as the provision of scholarly quality education to the benefit and advancement of society (Erguder, 2010). As such, academics at universities are privileged to exercise their academic freedom, which, inter alia, entails the freedom to conduct research and to select, develop and implement educational programmes free from external intervention (CEPES, 1992, p. 10; Council on Higher Education, 2006, p. 16; Erguder, 2010). The Council on Higher Education (2006, p. 16) recognizes this autonomy as the freedom the academy enjoys from outside interference, which includes the freedom of academics to teach and conduct research without interference.

Badat (2009, p. 4) argues that universities are characterized by different missions, varied social and educational purposes and goals, different sizes, different configurations of academic programmes, different admission requirements and varied academic standards that are compliant with specified purposes and goals. A university provides an ideal setting for academics to impart their knowledge and to develop it through research and innovation (Erguder, 2010). Academics have the freedom and the right to conduct academic practices in ways that recognise their autonomy, while, at the same time, observing their duty to do so in a way that recognises and adheres to various social norms. In the South African context these would involve issues, such as the right to access education, as well as the need to reflect on the content of the curriculum to ensure that it meets the demands posed by a diverse student population and the unique context of the country (Council on Higher Education, 2006, p. 17).

Currently eleven universities in South Africa offer early childhood education (ECE) as part of their teacher training programmes. These universities offer literacy, numeracy (mathematics) and life skills, and it is evident that they use the National Curriculum Statement (NCS), or the Curriculum Assessment Policy Statements (CAPS) as guides for compiling their various ECE programmes. These two documents, the CAPS document being the most recent, represent the policies for learning and teaching in South African schools. The purpose of this paper is to investigate how these eleven universities in South Africa offer the subject life skills, one of the three subjects areas that constitute the foundation phase curriculum as well as programmes of pre-service teacher education and training. We do not investigate the content of the life skills subject area at the respective universities, but explore how universities exercise their academic freedom and institutional autonomy in the structuring their life skills programme. More particularly, the paper focuses on how the different aspects of the life skills subject area are offered in terms of credits, duration, naming of aspects and the year of implementation. 


\section{The necessity of life skills in the foundation phase curriculum}

Internationally there seems to be a growing awareness and recognition of the demands and challenges that young children have to cope with. "What happens to children in their first days, months and years of life affects their development, the development of our society and the development of our world," according to the Bernard van Leer Foundation (2004, p. 3). Elliot \& Davis (2009, p. 113) argue that during the early years of development children demonstrate the greatest ability to learn and develop. For this reason, it is crucial that nations invest in their young, thereby preparing and equipping them for future challenges. The subject "Life Skills" presents an opportunity to address all the various aspects of ECD in an integrated manner. In the CAPS document (DBE, 2012, p. 9) this view is echoed by the aim of the subject, which is described as "... guiding and preparing learners for life and its possibilities, including equipping learners for meaningful and successful living in a rapidly changing and transforming society." The importance of such a subject is further highlighted by Mbebeb (2009, p. 22) who quotes the United Nation's Economic Commission for Africa (UNECA, 2006) who refers to young people as "... agents of change with the potential of taking a leading role in tackling Africa's future development challenges".

Aidoo (2008) maintains that ECE is the foundation of human development in that it provides an opportunity for sustainable development, economic growth, social change and transformation in society. Mbebeb (2009, p. 24) remarks that "[c] hildhood development has been positioned at the centre of human development as a foundation for a wholesome personality, productive life skills and it requires a relevant and qualitative education." Similarly, UNICEF (2009b) affirms that child stimulation and development at this early stage of life are indispensable for good health, growth, success in education and in life. UNICEF report states that "[n]utrition and clean water, caring families and communities, support for early learning and psycho-social development, and access to health care are among the jointly necessary conditions for young children's survival and well-being, and for their healthy development through later childhood into well-functioning adulthood" (UNICEF, 2009a, p.46). This report concludes by stating that ECE has a crucial role in children's realization of their rights to survival, development, protection and participation.

Johannsen (2009, p. 81) highlights the responsibility and necessity of ECE in the formative early childhood years "...for assisting the future adult citizens of the world to be moral and respectful individuals." Due to widespread family disintegration, Berson \& Baggerly (2009, p. 375) argue, the school should take the responsibility to protect children and "... serve as a bridge for the family and community, allowing development of a social network for the child." McDevitt and Ormrod (2007, p. 31) also make mention of the changing task of the school when they remark that "... $\mathrm{t}$ ] hroughout history, the family was expected to support the school. More recently, the school is being asked to support the family." In this regard, Joseph \& Strain (2003) report on research in South Africa by the National Research Council and Institutes of Medicine, which has revealed that early experiences and relationships at home and school set the stage for how a child learns self-regulation skills, as well as the ability 
to manage emotions, take the perspective of others, and develop close relationships with other people. Similarly Schoeman (2005) maintains that learners have to be prepared for their future responsibilities as citizens of a democratic society, and she concludes that "[s]chools [...] bear a special and historic responsibility for the development of civic competency and responsibility" (2005, p. 275). Vuckovic (2008) believes that primary socialization takes place during the early years, and he defines it as the internalisation of values and attitudes “... as well as preferences and habit patterns...," which leave a sustained impact on the individual. Formal ECE is crucial in creating a supportive environment wherein young children can develop at all levels.

It is clear that the emphasis in ECE should not only be on academic knowledge, but that it should recognize the importance of equipping young children with nonacademic knowledge and skills as well. Joseph \& Strain (2003, p. 65) refer to the latter as "... social-emotional curricular programs..." and they describe them as focusing on "... protective factors and reducing risk factors associated with academic and social problems." In other words, non-academic knowledge involves survival and coping skills to assist an individual in overcoming specific challenges that may be faced in all dimensions of life. Finn (2006) points to the fact that there has been a paradigm shift worldwide with regard to the aims of education, so as to include non-academic ${ }^{1}$ subjects in school curricula in order to meet the needs of an increasing diverse and globalised community.

\section{Including non-academic subject matter in a school curriculum}

Koo, Kam \& Cheong (2003) report on the development of a new culture of learning and teaching where non-academic subjects are included in the school curriculum to meet "...the context of political dispensations" (2003, p. 137). Governments all over the world view education as a tool to inculcate certain dispositions, values and skills to equip their future citizens in order to guarantee survival, peace, progress and sustainability.

Ransford, Greenberg, Domitrovich, Small \& Jacobson (2009, p. 510) report on the PATHS curriculum (Promoting Alternative Thinking Strategies) in the United States and Australia, which provides learners with instruction in the areas of emotional awareness and understanding, self-control, social skills with peers and social problem-solving skills in order to promote their social and emotional competence. Otote \& Omo-Ojugo (2009, p. 654) also provide an account of Nigerian schools where social studies as a subject encourages the development of socio-civic and personal behaviour, thereby focusing on the affective domain of learning. Snel, Ganguly \& Shordt (2002, p. 9) report on the Nali-Kali approach used in Indian schools, which aims to "...create awareness and bring about behavioural change among children and through them, in parents and the community in selected districts." This curriculum focuses on hygiene

1 "Non-academic" in this context refers to subjects and curricula that focus first and foremost on knowledge and skills that do not form part of conventional "academic" subjects such as, for example, Mathematics, History, Chemistry, etc. 
education and environmental sanitation. The subject life skills makes provision for a non-academic subject within the South African schools' curriculum.

\section{How does South Africa accommodate non-academic subject matter?}

In South Africa the value and significance of ECD is recognized and acknowledged by the government and various other role players. The government's commitment to the development of young children is mirrored in the Bill of Rights in South Africa's Constitution and from the country's agreement with conventions, such as the African Charter on the Rights and Welfare of the Child and the United Nations Convention of the Rights of the Child. The department of basic education (DBE) underwrites the importance of ECD, and its dedication to quality education for young children is reflected in the new curriculum (2012). The subjects that have been selected for the foundation phase level (5-9 years of age) are the following: home language, first additional language, mathematics and life skills. The value of non-academic subject matter is recognised and subsequently addressed by the inclusion of life skills.

\section{What are life skills?}

Life skills are the personal and social skills required for people (in this case young children) to think and behave competently and confidently in dealing with themselves, relating to others and making effective decisions. According to the World Health Organisation (1999, p. 6) "Life Skills education is designed to facilitate the practice and reinforcement of psycho-social skills in a culturally and developmentally appropriate way. It contributes to the promotion of personal and social development, the prevention of health and social problems and the protection of human rights." According to Rooth (1997, p. 6), life skills are essential for successful living and learning. Its point of departure is the belief that as a person develops more life skills, the possibility increases that the individual would be better equipped to deal with challenges, and even to avert some of them. Epstein (2003, p. 28) remarks that although contemporary early childhood teachers often focus on enhancing reading and mathematical skills to meet ever increasing academic expectations, teachers must remain committed to promoting broader thinking abilities. Life skills provide the foundation upon which children learn to make decisions, regulate their own behaviour, meet complex challenges and take responsibility for their actions.

\section{Life skills as a subject}

The new curriculum (DBE, 2012) describes life skills as a subject that is pivotal to the holistic development of learners. The subject is concerned with the social, personal, intellectual, emotional and physical growth of learners and it comprises the following study areas: beginning knowledge, creative arts, physical education, and personal and social wellbeing. The latter have been organised as study areas to ensure that 
the foundational skills, values and concepts of early childhood development and the subjects offered in Grades 4-12 are taught and developed in Grades R-3 (DBE, 2012, p. 8).

According to the CAPS document (2012), the aim of life skills is to prepare learners for all the challenges they will be facing in life, and to equip them to live meaningfully and successfully in a "... rapidly changing and transforming society" (DBE, 2012, p. 9). The subject exposes learners to a range of knowledge, skills and values that will strengthen their holistic (physical, social, personal, emotional and cognitive) development, creative and aesthetic knowledge and skills, knowledge of personal health and safety, understanding of the relationship between people and the environment and learners' awareness of social relationships, technological processes and elementary science.

\section{The subject Life Skills is unpacked as follows:}

\section{Beginning knowledge}

The content of beginning knowledge has been drawn from life orientation, social sciences (history and geography); natural science and technology. The content has been organized into topics that focus mainly on:

- the child and his/her relationship with his/her immediate family extending to the wider community;

- the natural environment (flora, fauna, natural resources, etc.);

- South Africa (diverse people - cultures, customs, national symbols);

- Environmental awareness events (Water Week, Arbor Day, Marine Day, etc.);

- National/Public holidays (Heritage Day, Freedom Day, Youth Day, etc.);

- Special celebrations (Days) observed in South Africa by diverse cultural groups.

\section{Health education}

The content for Health Education has been drawn mainly from Life Orientation and will focus on topics dealing with:

- personal hygiene and cleanliness;

- healthy eating, nutrition and fitness;

- communicable diseases including HIV/AIDS;

- health services (clinics, hospitals, ambulance, etc.);

- health awareness events (e.g. Dental, Eye, Organ Week, etc.);

- safety in the home and school and road safety.

\section{Art and crafts}

The content has been drawn from the arts and culture learning area. The four components of art and crafts are dance, music, drama and art and crafts. Children in grades R - 3 should be exposed to all four creative art forms. Where feasible, these art forms can be integrated, for example:

- Dance can be infused with physical education and music;

- Drama and music can be infused with languages (speech, oral skills, storytelling, role-play, voice projection through singing); and,

- Art and crafts, music and dance can be infused with mathematics (e.g. shape, pattern, time, counting, distance, size and direction). 


\section{Physical education:}

The content for physical education has been drawn from life orientation. The emphasis is on developing children's fine and gross motor skills mainly through:

- Physical movement activities (locomotive, climbing and balancing);

- Games (including traditional and indigenous games);

- Elementary sports activities (athletics, netball, cricket and soccer skills, etc.)

\section{Problem statement}

A recent study by Mosia (2011) found that the majority of teachers experience difficulties with the implementation of this subject, mainly due to a lack of training. Teachers maintain that they are not equipped with the required knowledge and skills to teach the subject, and they admit to utilising the time allocated to life skills on the timetable for other things just to keep the learners occupied. In this regard one teacher remarked: "I sometimes wonder if learners are aware that we are not doing justice to them and we are also held accountable for their weak performance" (Mosia, 2011, p. 98). Mosia's study indicates that higher education institutions do not adequately prepare teachers for the teaching of life skills. Her observation resonates with Rooth (2005) who reported that $75 \%$ of the Intermediate and $54 \%$ of the senior phase LO teachers in her study were not specialists in LO. She concluded that "[i]t would be a devastating loss of an educationally sound opportunity if Life Orientation could not fulfil its potential to make a vital contribution to learners' successful living, learning and well-being" (Van Deventer \& Van Niekerk, 2009, pp. 148-149). Both these studies recommend that universities should prepare their student teachers for teaching practice by equipping them with the relevant knowledge and skills to teach life skills. We use the new curriculum as guideline to explore how different higher education institutions (HEIs) offer life skills in preparing teachers for teaching practice.

\section{Research methodology}

\section{Aims of the research project}

The primary aim of this study is to investigate how life skills as a subject is offered to the B.Ed foundation phase student teachers at HEls in South Africa. The following secondary aims are addressed:

- $\quad$ to identify similarities and differences in the offering of life skills at HEls;

- to establish the extent to which life skills in HEls attend to the various aspects as outlined in the CAPS document.

\section{Research design}

A qualitative research method was used and semi-structured interviews were conducted with lecturers. A purposive sample was drawn for the semi-structured 
interviews. The sample population consisting of nine respondents from the respective institutions were chosen for their expertise relating to the lecturing of life skills. Open-ended questions were used to obtain information and the purpose was not to get information on the content of each aspect of life skills, but rather to determine how HEls offer the aspects of the subject. Document analysis was done by analysing the information of the year books of the relevant HEls. The interviews were audiotaped and transcribed and used to verify information from the year books of the HEls. Pseudonyms for the various universities are used when the findings are discussed.

\section{Data analysis}

The CAPS document was used as a framework to analyse and discuss the data according to the modules, credit allocation and time allocation of each module.

\section{Findings and discussion}

The findings of the study are discussed according to the requirements of the CAPS document, i.e. beginning knowledge, health education, arts and crafts and physical education.

\section{Beginning knowledge}

The content for beginning knowledge is drawn from the fields of life orientation, social sciences (history and geography), natural sciences and technology. To enable foundation phase teacher students to equip learners with beginning knowledge, they should be empowered with content from the above mentioned subject areas.

\section{Life orientation or life skills}

With regard to the module life orientation, different credits are allocated and different module names are used at HEls as illustrated in Table 1.

All nine universities offer life orientation or life skills as modules or year courses, but it seems that there is a huge discrepancy in the credit allocation since it ranges between 5 and 48 credits. University A offers life skills but the module is linked to the separate modules, which are environmental studies (Table 2), health education (Table 4), nutrition (Table 4), life skills: culture and religion (Table 5), life skills: art (Table 5), life skills: music (Table 5) as well as life skills: physical education (Table 6).

In one interview a participant (University E) indicated that the module on "Integrated Learning Area Studies: Life Skills" contains life skills content as well as creative arts and physical education or sports science: "In the 'Integrated Learning Area Studies' module the focus is also on Creative Arts which include Dance, Music, Drama, Visual Art and Performing Arts." 
Table 1: Names of modules referring to Life Orientation

\begin{tabular}{|c|c|c|c|c|}
\hline HEI & Module name & $\begin{array}{l}\text { Year of } \\
\text { study }\end{array}$ & Credits & Total \\
\hline A & Life Skills linked to separate modules & & & \\
\hline B & $\begin{array}{l}\text { Life Skills: Personal and Social } \\
\text { Development }\end{array}$ & 2 & 6 & 6 \\
\hline C & $\begin{array}{l}\text { Human and Social Sciences (Life } \\
\text { Orientation) } \\
\text { Integrated approach to Teaching and } \\
\text { Learning of Life Skills } 3 \text { A and } 3 \text { B } \\
\text { Human and Social Sciences } 4 \text { B (Life } \\
\text { Orientation) }\end{array}$ & $\begin{array}{l}2 \\
3 \\
4\end{array}$ & $\begin{array}{l}12 \\
24 \\
12\end{array}$ & 48 \\
\hline D & $\begin{array}{l}\text { Life Skills Education } \\
\text { Early Childhood Social Care }\end{array}$ & $\begin{array}{l}4 \\
4\end{array}$ & $\begin{array}{c}16 \\
8\end{array}$ & 24 \\
\hline E & $\begin{array}{l}\text { Integrated Learning Area Studies: } \\
\text { Life Skills } \\
\text { Life Skills Learning Area Studies }\end{array}$ & $\begin{array}{l}3 \\
4\end{array}$ & $\begin{array}{l}16 \\
16\end{array}$ & 32 \\
\hline $\mathbf{F}$ & Grade R Life Skills & 1 & 5 & 5 \\
\hline G & $\begin{array}{l}\text { Life Orientation: Multi-religion and } \\
\text { Multi-culture }\end{array}$ & 3 & 10 & 10 \\
\hline H & $\begin{array}{l}\text { Foundation Phase studies: Year } 2 \\
\text { Foundation Phase studies: Year } 3\end{array}$ & $\begin{array}{l}2 \\
3\end{array}$ & $\begin{array}{l}16^{*} \\
24^{*}\end{array}$ & $40^{*}$ \\
\hline $\mathbf{I}$ & $\begin{array}{l}\text { Life Skills: Personal and Social } \\
\text { Development \& Health Education } \\
\text { Method- Life Skills Year } 2\end{array}$ & $\begin{array}{l}1 \\
2\end{array}$ & $\begin{array}{l}10 \\
10\end{array}$ & 20 \\
\hline
\end{tabular}

*These credits include the didactics for all three learning areas, namely Literacy, Mathematics and Life Skills

The module, "Life Skills Learning Area Studies" (University E), includes content on nutrition, safety at home and at school, creative arts and physical education. The participant indicated that the abovementioned two modules would be retained, but "... the Human Movement module and Nutrition need to be developed and recurriculated." The participant indicated overlaps in the two modules, but explained that all third and fourth year students "... had to be introduced to the content of the new CAPS document". The assembly of different aspects to constitute beginning knowledge is confusing. This is affirmed by Rooth (in Van Deventer \& Van Niekerk 2009, p. 154) who refers to the multitude of definitions and subsequent various interpretations of what LO entails. 


\section{Social sciences}

Regarding social sciences and environmental studies only seven HEls offer modules or year courses in history and geography as well as environmental studies, and the credits range from 3 to 36 . One HEI (University D) offers three modules, namely environmental studies in year 1, pre-school learning environment and structure of learning in year 2 as well as foundation phase learning environment in year 2 . Eight credits are allocated to each module which adds up to a total of 24 credits. The course, environmental studies, is offered at University A ( 8 credits) and environment and the curriculum is part of the curriculum at University $\mathrm{G}$ ( 8 credits).

Table 2: Social sciences / Environmental Studies

\begin{tabular}{|c|c|c|c|c|}
\hline HEI & Module name & $\begin{array}{l}\text { Year of } \\
\text { study }\end{array}$ & Credits & $\begin{array}{l}\text { Total } \\
\text { credits }\end{array}$ \\
\hline A & Life Skills: Environmental studies & 3 & 8 & 8 \\
\hline B & Social Sciences & 2 & 6 & 6 \\
\hline C & $\begin{array}{l}\text { History } 1 \text { A } \\
\text { Geography } 1 \mathrm{~B} \\
\text { History } 4 \text { A } \\
\text { Geography 4A }\end{array}$ & $\begin{array}{l}1 \\
1 \\
4 \\
4\end{array}$ & $\begin{array}{l}12 \\
12 \\
6 \\
6\end{array}$ & 36 \\
\hline D & $\begin{array}{l}\text { Environmental Education } \\
\text { Pre-school Learning environment and } \\
\text { structure of Learning } \\
\text { Foundation Phase Learning } \\
\text { Environment }\end{array}$ & $\begin{array}{l}8 \\
8 \\
8\end{array}$ & $\begin{array}{l}1 \\
2 \\
2\end{array}$ & 24 \\
\hline $\mathbf{F}$ & $\begin{array}{l}\text { Human Social Sciences } \\
\text { Didactics : Life Skills } \\
\text { Didactics Integrated }\end{array}$ & $\begin{array}{l}3 \\
2 \\
3\end{array}$ & $\begin{array}{l}3 \\
5 \\
7\end{array}$ & 15 \\
\hline G & $\begin{array}{l}\text { Social Sciences } \\
\text { Environment and the curriculum }\end{array}$ & $\begin{array}{l}1 \\
3\end{array}$ & $\begin{array}{c}10 \\
8\end{array}$ & 18 \\
\hline I & $\begin{array}{l}\text { Introduction to Economic and } \\
\text { Settlement Geography } \\
\text { Introduction to World History A and B } \\
\text { Introduction to History of South } \\
\text { Africa A and B }\end{array}$ & $\begin{array}{l}3 \\
3 \\
3\end{array}$ & $\begin{array}{c}5 \\
12 \\
12\end{array}$ & 29 \\
\hline
\end{tabular}

At a particular HEI (University C), numerous module names relating to history and geography are included in the Life Skills module. In explaining this heavy weighting of social sciences, the participant remarked that this was " ...to inform their teaching of Life Skills. The understanding behind it is how can a teacher be able to teach Life Skills if he/she doesn't have the knowledge of Geography and History because History provides them with the attitudes and values that they need to focus on when teaching Life Skills. Geography exposes them to pollution and environmental awareness." 
In preparing today's learners to become productive citizens of the future our educational system is required to promote life-long learners who are able to work together to solve realistic problems and develop a basic understanding of the natural and humanly modified world around them. Information presented in a familiar and mind-engaging context leads to greater understanding and retention, as compared to memorization of facts in isolation (Harpine, Hickey \& Whiting, 2004, p. 28). Social sciences may equip the learners with the necessary knowledge and skills to solve problems and understand the world as a set of related systems.

\section{Natural science and technology}

Four universities (Universities B, D, F, G), as indicated in Table 3, offer modules on natural science and technology, whereas one university (University I) offers natural and life science. This implies that the other five universities that offer life skills, do not equip their student teachers with knowledge and skills to effectively teach natural science and technology. Van Heerden (2005, p. 80-81) argues that the importance of science and technology as subjects in the foundation phase curriculum is manifold. They provide opportunities for children to learn through doing and talking; to be involved in problem solving; to acquire a flexible approach; to approach problems in real contexts and to develop important personal qualities and attitudes such as creativity, co-operation and perseverance. Although science and technology activities are beneficial to learners, a number of teachers feel ill-equipped to present activities in these subjects. This view corresponds with research done by Bosman (2006, p. 234), which indicated that $50 \%$ of foundation phase teachers weren't trained in natural science during their initial teacher training. Yet, it is also true that the children love to do it, and it may additionally provide a great deal of satisfaction when they achieve a good result or end product. The key to success is the teachers' understanding of the design process. If teachers understand it their confidence will grow, which in turn would provide for a more rewarding and enjoyable experience for both the learners and the teachers (Gresham, 2003, p. 62). The inclusion of science and technology activities in the classroom helps to meet the cognitive, psychomotor, social and emotional needs of all learners. In the context of solving real-world problems through academic skills mastery, learners become innovators and inventors, also known as children engineers (Harpine, Hickey \& Whiting, 2004, p. 29 in Van Heerden, 2005).

The credits allocated to these modules in natural science and technology range from 5 to 20 and the modules are offered in different years of study.

Table 3: Natural Science and Technology

\begin{tabular}{|c|l|c|c|c|}
\hline HEI & \multicolumn{1}{|c|}{ Module name } & $\begin{array}{c}\text { Year of } \\
\text { study }\end{array}$ & Credits & $\begin{array}{c}\text { Total } \\
\text { credits }\end{array}$ \\
\hline B & Natural Science and Technology & 2 & 12 & 12 \\
\hline D & Technology Education & 3 & 16 & 16 \\
\hline F & Natural Science and Technology & 2 & 5 & 5 \\
\hline
\end{tabular}




\begin{tabular}{|c|l|c|c|c|}
\hline HEI & \multicolumn{1}{|c|}{ Module name } & $\begin{array}{c}\text { Year of } \\
\text { study }\end{array}$ & Credits & $\begin{array}{c}\text { Total } \\
\text { credits }\end{array}$ \\
\hline G & Natural Science & 1 & 10 & 20 \\
& Technology & 2 & 10 & \\
\hline I & Subject: Natural and Life Sciences & 3 & 10 & 10 \\
\hline
\end{tabular}

\section{Health education}

Health education as a separate module is only offered at four HEls, which is characterised by a wide range of credits and a variety of names. The lack of sufficient attention given to health, safety and nutrition is a concern. Poor safety, health and nutrition will adversely impact on a learner's physical and mental ability (Swart, Sanders \& McLachlan, 2008). In South Africa, thirteen per cent (13\%) of children admitted to the Rooi Kruis Children's Hospital in Cape Town in 2011, were treated for falls due to playground injuries, while sexual assault or rape accounted for thirty per cent $(30 \%)$ of all assault cases. Forty five per cent $(45 \%)$ of children were assaulted due to blunt force trauma whereas seventy six per cent (76\%) suffered burn injuries due to hot liquids or fluids (www.childsafe.org.za).

School health and nutrition programming is recognised as a tool to improve children's nutritional status, learning achievement and general well-being (UNICEF, 2009a). Research done by Del Rosso \& Marek (1996) as well as Levinger (1996) showed that healthy, well-nourished children possess learning capacity and the ability to engage fully in educational experiences. Furthermore, in 2009 UNICEF indicated that nine per cent ( $9 \%$ ) of children in South Africa under the age of five were moderately to severely underweight. A report by Berry, Hall \& Hendricks (2010, p. 121) revealed that eighteen per cent (18\%) of children live in households where they are malnourished. It was also found that eighteen per cent (18\%) of children aged between 1 and 9, suffer from stunted growth with five per cent (5\%) from severe stunting. This implies that student teachers in the foundation phase should be equipped with knowledge regarding nutrition, the identification of under-nutrition and malnutrition as well as the skills to find creative ways to address nutrition challenges at school.

Statistics revealed by the Children's Institute in 2012 indicate that the estimated overall HIV prevalence rate in 2011 was $10,6 \%$ while the total number of people living with HIV is estimated at approximately 5,38 million in 2012 (www.childrencount.ci.org. za). An estimated 63600 new HIV infections will be among children aged 0-14 years (Statistics SA, 2011). These statistics point at an increase in the number of learners that are orphaned or affected by HIV and AIDS. Schools need to work closely with parents and communities to protect these learners who are infected and affected by HIV (UNICEF, 2009a, p. 11). Furthermore, a study by Meintjies, Hall, Marera \& Boulle (2010, p. 42) found that 122000 children from an estimated total of 18.2 million households are child headed. Student teachers thus need to be equipped with knowledge and skills on health, safety and nutrition to support learners in this regard. 
At one HEl (University A) health education has 8 credits and is offered in year 2 along with separate module on nutrition carrying 8 credits in year 3. At another university (F) the module is called health and nutrition and is offered in year 1 with 5 credits, whereas health, safety and nutrition is offered in year 1 with 6 credits by University B. At University I it is known as curriculum studies: life skills: beginning knowledge and health education and it carries 5 credits. The credits vary from 5 to 16 and it is offered in different years at HEls.

Table 4: Health education, safety and nutrition for B. Ed foundation phase

\begin{tabular}{|c|l|c|c|c|}
\hline HEI & \multicolumn{1}{|c|}{ Module name } & $\begin{array}{c}\text { Year of } \\
\text { study }\end{array}$ & Credits & $\begin{array}{c}\text { Total } \\
\text { credits }\end{array}$ \\
\hline A & Life Skills: Health Education & 2 & 8 & 16 \\
& Life Skills: Nutrition & 3 & 8 & 6 \\
\hline B & Health, Safety and Nutrition & 1 & 6 & 5 \\
\hline F & Health and Nutrition & 1 & 5 & 5 \\
\hline I & Curriculum Studies: Life Skills: & 2 & 5 & \\
& $\begin{array}{l}\text { Beginning knowledge and Health } \\
\text { Education }\end{array}$ & & & \\
\hline
\end{tabular}

\section{Arts, crafts, drama and music}

Arts and crafts, as indicated in the CAPS document, include dance, music and drama. Arts and craft are presented at eight HEls. The credits range from 5 to 16 and the course is presented during year 1,2 or 3 at different HEls.

Two HEls offer music as a separate module (Universities A and D). At one $\mathrm{HEl}$ (University A), music is compulsory in year 1 and year 2 and it carries 26 credits, whereas childhood movement and music (University D) is presented in year 2 with 8 credits. Art, music and drama are offered as one course in year 1and 2 at University $F$ where it carries 10 credits while music and art is offered as a single course at University $G$ with 10 credits allocated to the course.

Dance and drama as a course is offered at three HEls in either year 3 or year 4. At one $\mathrm{HEl}$ (University $\mathrm{H}$ ) drama in education in the classroom as well as drama in education: participatory theatre forms, is offered in year 4 and they carry a total of 32 credits. Childhood Speech and drama is offered in year 3 at University D and 8 credits are allocated to the module. The course dance and drama is also offered in year 3 at University $G$ and it is worth 10 credits.

It seems that all eight universities regard arts and culture as important whereas music and drama is only offered at four universities. Although dance is specifically mentioned in the CAPS document, it seems from the table above that none of the universities pay much attention to this aspect. This could be because HEls hold the view that physical education includes dance. However, of some concern is the fact that music as a separate phase specific module is only offered at two institutions. A 
study by Catterall (in Fiske, 1999) that followed 25,000 children over a 10-year period revealed that children who were involved in drama and music had higher reading and mathematics skills. Furthermore, a three-year study called "Learning, Arts and the Brain" revealed that fine arts instruction could help to focus children's attention and improve their thinking skills (Gazzaniga, 2004).

Table 5: Arts and Craft, Drama and Music for B. Ed: Foundation Phase at HEls.

\begin{tabular}{|c|l|c|c|}
\hline HEI & \multicolumn{1}{|c|}{ Module/ course name } & Credits & Year of study \\
\hline A & Life Skills: Culture and Religion & 8 & 1 \\
& Life Skills: Art & 8 & 1 \\
& Life Skills: Music & 26 & $1 \& 2$ \\
\hline C & Arts and Culture & 12 & 1 \\
\hline D & Childhood Art & 8 & 3 \\
& Childhood Speech and Drama & 8 & 3 \\
& Childhood movement and music & 8 & 2 \\
\hline E & Creative Art & 16 & 3 \\
\hline F & Art, Music, Drama & 10 & 1 \\
\hline G & Music and Art & 10 & 3 \\
& Dance and Drama & 10 & 4 \\
\hline H & Drama in Education In the classroom & 32 & \\
& Drama in Education: Participatory & & 2 \\
& theatre forms & 5 & 1 \\
\hline I & Curriculum Studies: Life Skills: Arts & 10 & \\
& and Crafts and Physical Education & & \\
& Curriculum Studies: Arts & & \\
\hline
\end{tabular}

In the South African context where diversity at all levels is a reality in classrooms, music could serve as a uniting instrument. For instance, Gallegos (2006, p. 46) suggests that "... children's hearts and minds are the same when music is concerned." Music also seems to improve reading skills. Register, Darrow, Standley \& Swedberg, (2007, p. 27) refer to the correlation between music and reading skills and conclude that “... regardless of the method of literacy instruction, there is a growing body of literature that supports specific music experiences and activities in order to teach and practice essential literacy learning components utilizing both phonics and whole language approaches." Taking into account that The Annual National Assessment (ANA) of 2011, which reported on the assessment of more than 6 million Grade 3 learners and found that the average performance in Literacy was 35\% (Department: Basic Education, 2011), music as a subject which supports the development of literacy should be an integral part of the foundation phase curriculum. 


\section{Physical education}

Researchers on early childhood development unanimously emphasize the importance of physical activity for the overall development of a child. In this regard Krog (2010, p. 3) notes that "... movement is seen as contributing to the growth and development of the brain as it forms the building blocks on which later learning is based."

Van Deventer and Van Niekerk (2009, p. 147) report that the decline in physical activity among children is a worldwide phenomenon that goes hand in hand with the emergence of alarming health trends. Pate, Davis, Robinson, Stone, McKenzie \& Young (2006) suggest that schools need to revisit their responsibilities in providing and promoting physical activity. The conclusion that Van Deventer \& Van Niekerk (2009, p. 147) draw after their study on physical education in schools is formulated as follows: "Notwithstanding the damage done to the growth and development of the young child, the fact that a large number of schools do not have qualified PE teachers in their service affects the status and practice of LO negatively."

In investigating how physical education (PE) is addressed at HEls, it was found that PE is offered as a module at six HEls where only four of these institutions offer phase specific physical education and the other two present it in generic ally. In the foundation phase the focus is on learners' discovering, exploring and experimenting with movement pattern to stimulate gross motor development and physical growth (Sitzer, 2001, p 2). The range of credits allocated to this module indicates that all institutions value this component more or less equally.

Table 6: Physical education modules

\begin{tabular}{|c|l|c|c|c|}
\hline HEI & \multicolumn{1}{|c|}{ Module name } & $\begin{array}{c}\text { Year of } \\
\text { study }\end{array}$ & Credits & $\begin{array}{c}\text { Total } \\
\text { credits }\end{array}$ \\
\hline A & Life Skills: Physical Education & 3 & 8 & 8 \\
\hline B & Human Movement & 1 & 6 & 6 \\
\hline D & Physical Education and Health Education & 3 & 8 & 8 \\
\hline F & Human Movement & 1 & 5 & 5 \\
\hline G & Physical Movement & 3 & 10 & 10 \\
\hline I & Human Movement Science & 1 & 11 & 11 \\
\hline
\end{tabular}

\section{Other modules}

The courses didactics: life skills ( 5 credits offered in year 2) and didactics integrated (7 credits offered in year 3 ) is offered at University F. One participant explained that this is because "... students learn and see the subjects in isolation, for example Health and Safety, Human Movement, Arts.. (and) that's why we integrate everything in "Didactics Integrated". Edwards \& Protheroe (2003, p. 228) agree when they maintain that students tend to see teaching as an "individual performance" far removed from the classroom practice. An integrated approach where didactics and theory meet seems to address this concern. 


\section{Conclusion}

Although the authors are of the opinion that the new curriculum should be used as a guideline, it can be concluded that most of the HEls that offer the B.Ed foundation phase course, include knowledge and skills related to the four themes (as indicated in the CAPS document for life skills, 2011), namely beginning knowledge, health education, arts and craft, as well as physical education. The CAPS document informs most of the curricula. One participant remarked that "... we follow the CAPS. We wanted to make it easy for them to interpret the syllabus when they go to the school."

HEls should consider the inclusion of Natural Science and Technology as well as Health Education, Safety and Nutrition as subjects/modules in their Foundation Phase Teacher Training Programmes.

There are similarities as well as differences with regard to the names and credits given to the modules. This implies that universities attach different values to different modules. The term "Life Skills" is used at one HEI, another institution uses the term "Life Orientation" and "Integrated approach to Teaching and Learning of Life Skills", another uses "Grade R Life Skills General" whereas yet another HEI names the module "Life Skills Learning area Studies." Some module names, such as "Environmental Studies," have not yet been changed in accordance with the terminology of the CAPS document, but interviews revealed that most universities are engaged in the process of recurriculation. It signifies that there has been no collaboration between universities and that curriculation at the HEls is taking place in isolation which complicates the mobility of students between universities.

Many lecturers are newly appointed to the foundation phase area. One participant (university E) stated that "... we jumped in at the beginning of the year. We had to come up with the study manuals - we had only the outline." Another participant remarked: "I am new in the programme and I touch a little bit here and a little bit there. Am I doing all the right things?" This European Union research project which will facilitate the development of learning guides as open source material will benefit all lecturers and will strengthen collaboration and networking.

If life skills is regarded as one of the three important subjects for the foundation phase learner, HEls need to ensure that their student teachers are equipped with knowledge and skills to teach beginning knowledge, health education, arts and craft, as well as physical education. 


\section{References}

Aidoo, A.A, (2008). Positioning ECD Nationally: Trends in Selected African Countries. In M. Garcia, A. Pence, \& Evans, J. L. (Eds). Africa's Future, Africa's Challenge. Early Childhood Care and Development in Sub-Saharan Africa: (pp29-pp48). Washington, DC: The World Bank/ International Bank for Reconstruction and Development.

Badat, S. (2009, September). The Role of Higher Education in Society: Valuing Higher Education. Paper presented at HERS-SA Academy, Cape Town.

Bernard van Leer Foundation. (2004). Children are our future. Submission to the United Nations Committee on the rights of the child: Implementing Child Rights in Early Childhood. Retrieved from http://www.crin.org.

Benson, C. (1997). Design and technology: Key Stage 1 Scottish Levels A-B. Leamington Spa: Scholastic.

Berry, L., Hall, K. \& Hendricks, M. (2010). Child health: Nutrition .South African Child Gauge,2009-2010, 120-123. Cape Town: Children's Institute, University of Cape Town

Berson, I.R. and Baggerly, J. (2009). Building resilience to trauma: Creating a safe and supportive early childhood classroom. Childhood Education, 8(9), pp375-pp382.

Bosman, L. (2006). The value, place and method of teaching Natural Science in the Foundation Phase. (Unpublished master's dissertation). Unisa, Pretoria.

CEPES. (1992). Academic Freedom and University Autonomy. Proceedings of the International Conference. Sinaia, Bucharest.

Children's Institute. 2012. Statistics on Children in South Africa. Cape Town: University of Cape Town. Retrieved from http:// www.childrencount.ci.org.za.

Council on Higher Education. (2006). Academic Freedom, Institutional Autonomy and the Corporatised University in Contemporary South Africa.(CHE HEIAAF No.3) Pretoria: CHE.

Department: Basic Education. (2012). Curriculum and Assessment Policy Statement. Pretoria: DBE.

Department: Basic Education. (2011). Report on the Annual National Assessment Pretoria: DBE.

Del Rosso, J. M. \& Marek, T. (1996). Class action; improving school performance in the developing world through better health and nutrition. Washington, DC:The World Bank.

Edwards, A. \& Protheroe, L. (2003). Learning to see in classrooms: what are student teachers learning about teaching and learning while learning to teach in schools? British Educational Research Journal, 29(2), pp227-pp242.

Elliot, S. \& Davis, J. (2009). Exploring the resistance: An Australian perspective on educating for sustainability in Early Childhood. International Journal of Early Childhood, 41(2), pp65-pp77.

Epstein, A.S. (2003). How planning and reflection develop young children's thinking skills. Young children, September 2003, pp28-pp36. 
Ergüder, Ü. (2010,June). Academic Freedom And Institutional Autonomy: Contemporary Challenges. Paper presented at the IAU International Conference, Vilnius.

Finn, J. D. (2006). The Adult Lives of At-risk Students (NCES report 2006-328). Washington, DC: U.S. Department of Education, Institute of Education Sciences, National Center for Education Statistics.

Fiske, E.B. (2000). Champions of Change: The Impact of the Arts on Learning. GIA Reader: 11(1), pp1. Retrieved from http://www.giarts.org

Gallegos, J. \& Jellison, J.A. (2006). Music and Children with Special Needs. Intervention in School \& Clinic, 42(1), pp46-pp50.

Gazzaniga, M. S. (2004). Learning , Arts and the Brain. New York: Dana Press

Gresham, H. (2003). Design and technology: One I made earlier. Child Education. October 2003, pp. 62- pp63.

Harpine, L., Hickey, M. \& Whiting, G. (2004). An elementary school technology education curriculum resource guide. The Technology Teacher, 63(4), pp28-pp29.

Johannson, E. (2009). The preschool child of today - the world citizen of tomorrow? International Journal of Early Childhood,41(2), pp79-pp95.

Joseph, G.E. \& Strain, P.S. (2003). Comprehensive Evidence-Based Social-Emotional Curricula for Young Children: An Analysis of Efficacious Adoption Potential. Topics in Early Childhood Special Education, 23(2), pp65-pp79.

Koo, R. D., Kam, M. C. K. \& Choi, B. C. (2003). Education and Schooling in Hong Kong: Under One Country, Two Systems. Childhood Education, 79(3), pp137-pp155.

Krog, S. (2010). Movement programmes as a means to learning readiness. (Unpublished master's dissertation). Unisa, Pretoria.

Levinger, B. (1996). Nutrition, Health and education for all. Newton:Massachusetts.

Mbebeb, F.E.(2009). Developing productivelife skills in children: priming entrepreneurial mindsets through socialisation in family occupations. International Journal of Early Childhood, 41(2), pp23-pp34.

McDevitt, T.M. \& Ormrod, J.E. (2007). Child Development and Education. $3^{\text {rd }}$ edition. New Jersey: Pearson Prentice Hall.

Meintjies, H., Hall, K., Marera, D. \& Boulle, A. (2010) Orphans of the AIDS epidemic? The extent, nature and circumstances of child-headed households in South Africa. AIDS care, 22(1), pp40-pp49.

Mosia, D. (2011). Secondary school teachers' understanding, response to and implementation of Life Orientation. (Unpublished doctoral thesis). University of Pretoria, Pretoria.

Otote, C.O. \& Omo-Ojugo, M. (2009). Influence of teacher characteristics on affective evaluation of Social Studies teachers in Nigeria. Education, 129(4), pp654-pp665.

Pate, R.R.; Davis, M.G.; Robinson, T.N. ; Stone, E. J. \& Thomas, L. (2006). Promoting Physical Activity in Children and Youth: A leadership role for teachers. Retrieved from https://www.jyu.fi/sport/opiskelijavalinta/artikkelit/mckenzie/at.../file 
Ransford, C.R.; Greenberg, M.T.; Domitrovich, C. E. ,., Small, M. and Jacobson, L. (2009). The role of teachers' psychological experiences and perceptions of curriculum supports on the implementation of a social and emotional learning curriculum. School Psychology Review, 38 (4), pp510-pp1001.

Register, D., Darrow, A.A., Standley, J. \& Swedberg, O. (2007). The Use of Music to Enhance Reading Skills of Second Grade Students and Students with Reading Disabilities. Journal of Music Therapy, 44(1), pp23 - pp37.

Rooth, E. (1995). Life skills: A resource book for facilitators. Manzini: Macmillan.

Rooth, E. (1997). Introduction to Life Skills: Hands-on Approaches to Life Skills Education. Cape Town: Via Africa

Schoeman, S. (2005). Educating Democratic Minds in South African Public Schools: African Teachers' Perceptions of Good Citizenship. The Journal of Negro Education, 74(3), pp275-pp286.

Sitzer, J. (2001, November). Life Orientation: a learning area in South African schooling curriculum. Paper presented at the Southern African Congress in Sport Sciences, University of Stellenbosch.

Snel, M., Ganguly, S. \& Shordt, K. (2002). School sanitation and hygiene education India: Handbook for teachers. Delft: Giethoorn ten Brink.

Statistics South Africa. 2011. Midyear Population Estimates. Retrieved from http:// www.statssa.gov.za.

Swart, R., Sanders, D. \& McLachlan, M. (2008). Nutrition: A primary health care perspective. In Barron, P. \& Roma-Reardon, J. (Eds). South African Health Review. (pp129-147). Durban: Health Systems Trust.

The World Health Organization (2003). Skills for Health: Skills-based Health Education including Life Skills: An Important Component of a Child-Friendly/ HealthPromoting School. WHO Information series on School Health. Document 9. Switserland: World Health Organisation

UNICEF. (2009a). Situation analysis of children in South Africa. New York: Unicef

UNICEF. (2009b). The Child Friendly Schools Manual. New York: Unicef

Van Deventer, K.J. \& Van Niekerk, E. (2009). Life Orientation in the Foundation Phase (Grades R-3): A survey in selected Western Cape primary schools. South African Journal for Research in Sport, Physical Education and Recreation, 31(2), pp147-pp162.

Van Heerden, J. C. 2005. Implementation of the Learning Area Technology in Primary Schools in Gauteng and Free State Provinces. (Unpublished master's dissertation). TUT, Pretoria.

Vuckovic, A. (2008). Making the Multicultural Learning Environment Flourish: The Importance of the Child-Teacher Relationship in Educating Young Children about Diversity. Australian Journal of Early Childhood, 33(1), pp9-pp17. 